Arizmendi, M., L. Nuñez-Rosas, H. Berlanga, M. Quiroga Rodríguez, J. Soberanes González, C. Macias Caballero, R. Vidal Rodriguez, and G. López-Segoviano. 2021. Endemic and endangered Short-crested Coquette (Lophornis brachylophus): floral resources and interactions. Avian Conservation and Ecology 16(1):13. https://doi.org/10.5751/ACE-01834-160113

Copyright (C) 2021 by the author(s). Published here under license by the Resilience Alliance.

Research Paper

\title{
Endemic and endangered Short-crested Coquette (Lophornis brachylophus): floral resources and interactions
}

\author{
María del Coro Arizmendi ${ }^{1}$ (D), Laura E. Nuñez-Rosas ${ }^{1}$ (D), Humberto Berlanga ${ }^{2}$, Mónica A. M. Quiroga Rodríouez ${ }^{1}$, José Manuel \\ Soberanes González ${ }^{1}$, Claudia Macias Caballero ${ }^{3}$, Rosa María Vidal Rodriguez ${ }^{3}$ and Gabriel López-Segoviano 4 \\ ${ }^{1}$ Facultad de Estudios Superiores Iztacala, Universidad Nacional Autónoma de México, ${ }^{2}$ Comisión Nacional para el Conocimiento \\ y Uso de la Biodiversidad (CONABIO), ${ }^{3}$ Pronatura Sur A. C., ${ }^{4}$ Escuela Nacional de Estudios Superiores Campus Morelia
}

\begin{abstract}
The Short-crested Coquette (Lophornis brachylophus) is an endangered species endemic to Mexico. Currently, its distribution area is estimated at $53 \mathrm{~km}^{2}$. Little to no information exists on its natural history, abundance, and distribution. The purpose of the present study is to describe its food resources, behavior, and interactions with plants and other hummingbirds in addition to its abundance and distribution along an altitudinal gradient. We found that the Short-crested Coquette is sparsely distributed and ranges from tropical sub-deciduous forest to cloud forest. It can also occupy cultivated lands and forests with shade coffee plantations. It moves along an altitudinal gradient following the blooming of its floral resources, similar to other hummingbird species in the study region. It is a generalist, subordinate species that shares its distribution with 14 other hummingbird species. It interacts with some of these hummingbirds and plants in a nested network of interactions with low levels of connectance, visiting 8 of the 23 plant species commonly used by hummingbirds in the area. More in-depth studies on its reproduction and interaction with different plants and important crops in the area are required. The results of the present study can be used to propose programs for the management, conservation, or recovery of the habitats inhabited by the Short-crested Coquette and other hummingbirds.
\end{abstract}

\section{Coquette du Guerrero (Lophornis brachylophus), espèce endémique et en voie de disparition : ressources florales et interactions}

RÉSUMÉ. La Coquette du Guerrero (Lophornis brachylophus) est une espèce en voie de disparition, endémique du Mexique. Son aire de répartition actuelle est évaluée à $53 \mathrm{~km}^{2}$. On n'en connait peu, voire pas du tout, sur ses traits comportementaux, son abondance et sa répartition. L'objectif de la présente étude était de décrire ses ressources alimentaires, son comportement et ses interactions avec les plantes et les autres colibris, ainsi que son abondance et sa répartition le long d'un gradient altitudinal. Nous avons constaté que la répartition de la Coquette du Guerrero est clairsemée et s'étend de la forêt tropicale sub-décidue à la forêt brumeuse. La coquette fréquente également les terres cultivées et les forêts comportant des plantations de café d'ombre. Elle se déplace le long d'un gradient altitudinal en suivant la floraison de ses ressources florales, comme le font les autres espèces de colibris de la région d'étude. Il s'agit d'une espèce généraliste et subordonnée, qui partage sa répartition avec 14 autres espèces de colibris. Elle interagit avec certains de ces colibris et plantes dans un réseau imbriqué d'interactions à faibles niveaux de connectivité, visitant 8 des 23 espèces végétales communément utilisées par les colibris dans la région. Il serait nécessaire de mener des études plus approfondies sur sa reproduction et ses interactions avec différentes plantes et cultures importantes dans la région. Nos résultats peuvent servir à proposer des programmes de gestion, de conservation ou de restauration des habitats fréquentés par la Coquette du Guerrero et d'autres colibris.

Key Words: conservation; food resources; interactions; Short-crested Coquette

\section{INTRODUCTION}

The genus Lophornis (10 species) belongs to the Coquettes phylogenetic clade (McGuire et al 2009, 2014). It is distributed principally in lowland habitats from Mexico to Central America and South America (Colombia, Ecuador, Peru, Bolivia, Brazil, and Argentina; Freymann and Schuchmann 2005), where the Short-crested Coquette (Lophornis brachylophus) and Blackcrested Coquette (L. helenae) represent the northernmost species in Mexico (Schuchmann 1999).

The Short-crested Coquette is an endemic Mexican species, and according to McGuire et al. (2014) is considered monotypic. The
Short-crested Coquette is critically endangered according to the International Union for Conservation of Nature (IUCN) and is classified as endangered according to Mexican law (NOMECOL-059: SEMARNAT 2010). It is only known to inhabit a strip of about $25 \mathrm{~km}$ long between Atoyac, Paradise, and Puerto Gallo (Guerrero, Mexico). Birdlife International(2011) estimated that its population is between 250 and 999 individuals over a range of $53 \mathrm{~km}^{2}$, with densities between 3.6 and 18 individuals per square kilometer and a population decline between $10 \%$ and $19 \%$ mainly due to habitat loss.

Several factors affect hummingbird species and their populations; however, habitat loss is one of the main problems (Lindberg and

Address of Correspondent: María del Coro Arizmendi, Facultad de Estudios Superiores Iztacala, Universidad Nacional Autónoma de México., Laboratorio de Ecología, UBIPRO, Av. De los Barrios 1, Los Reyes Iztacala, Tlanepantla Edo. De México, CP 54090, coro@unam.mx 
Olesen 2001, Estades et al. 2007, Anderson et al. 2010, Freile et al. 2011, Rodrigues and Rodrigues 2011). For species restricted to particular areas with a low number of individuals, such as the Short-crested Coquette, the effect of habitat loss can be even more critical. Using potential distribution models, Sierra-Morales et al. (2016) estimated that the Short-crested Coquette has lost approximately $1422 \mathrm{~km}^{2}$ of its potential range due to habitat loss as a result of anthropogenic activities. More recently, $52 \%$ of the vegetation along the gradient has been lost.

The Short-crested Coquette is found in the Atoyac cloud forest, between semi-deciduous tropical forest and pine-oak forest. The Mexican cloud forests occupy less than $1 \%$ of the territory and host high biodiversity (CONABIO 2019, Navarro-Sigüenza et al. 2014), and are the most threatened terrestrial ecosystems nationwide(CONABIO 2019, Ornelas et al. 2013). Mexican cloud forests are the most used environment for shade-coffee plantations (CONABIO 2019), and this is also the main economic activity at the Sierra de Atoyac (González-González and HernándezSantana 2016).

The region where this species is distributed has been characterized by presenting social conflicts (Argüello Cabrera 2019). People are poor and the primary sources of income are coffee farming and, for a long time, the planting of poppies (González-González and Hernández-Santana 2016, Argüello-Cabrera 2018, 2019). Therefore, studies of the birds of the region are scarce despite its great biological importance.

Despite the high importance of the Sierra de Atoyac for conserving biodiversity, there are no protected natural areas (Navarro 1992, Arizmendi et al. 2016). The region hosts many hummingbird species (Arizmendi et al. 2016), including two of the most critically endangered hummingbird species with restricted distributional ranges (L. brachylophus and Eupherusa poliocerca; Berlanga et al. 2008). Accordingly, the purpose of the present study was to describe the abundance, floral resources, and interactions of the Short-crested Coquette in order to propose more effective conservation measures. To do this we first, 1) estimated the spatial distribution model of the Short-crested Coquette; then, 2) evaluated the abundance of Short-crested Coquette and of the other hummingbird species and their floral resources; 3) determined the plant species visited by Short-crested Coquette and the role of this hummingbird within ecological networks; and finally (4) evaluated the feeding behavior of Shortcrested Coquette.

\section{METHODS}

\section{Study area and data collection}

Sierra de Atoyac is located in the southwestern Sierra Madre del Sur, Mexico. It extends from western Guerrero to the southcentral part of Oaxaca (Navarro 1992). It is located between $17^{\circ}$ $15^{\prime}-17^{\circ} 45^{\prime} \mathrm{N}$ and $100^{\circ} 10^{\prime}-100^{\circ} 20^{\prime} \mathrm{W}$ along an altitudinal gradient between 300 and $2450 \mathrm{~m}$ asl (Vargas-Fernández et al. 1992). Lopez-Ramos (1983) placed the area within the geologic provinces of the Sierra Madre del Sur and Oaxacan Highlands. Rzedowski(1978) placed it in the floristic province of the southern mountains. It contains semi-deciduous tropical forest with disturbed coffee-growing areas found in the lowlands (300-820 m asl) along with an ecotone between tropical deciduous forest and cloud forest, cloud forest between 1400-2000 m asl, pine-oak forest between 2000-2600 m asl, pine forest above $2600 \mathrm{~m}$ asl, and Abies forest above $3100 \mathrm{~m}$ asl (Navarro 1992).

The study was conducted in 2011 (March, June to October) in three sites representing different habitats: Paraiso (17 $17^{\circ} 57.62$ " $\mathrm{N}$ and $100^{\circ} 10^{\prime} 17.99^{\prime} \mathrm{W}$ ) between 1000-1200 $\mathrm{m}$ asl with tropical deciduous forest and coffee plantations, Nueva Delhi ( $17^{\circ} 25^{\prime} 9.24$

" $\mathrm{N}$ and $100^{\circ} 11^{\prime} 33.88^{\prime \prime} \mathrm{W}$ ) between $1200-1500 \mathrm{~m}$ asl with cloud forest and coffee plantations, and El Molote (17 $25^{\circ} 11.49^{\prime \prime} \mathrm{N}$ and $\left.100^{\circ} 10^{\prime} 14.01^{\prime \prime} \mathrm{W}\right)$ between $1600-1800 \mathrm{~m}$ asl with cloud forest, oak-pine forest and coffee plantations (see Appendix Table 1). Due to accessibility, climatic conditions, and social conflicts, only six visits to each of the habitats were possible.

\section{Hummingbird surveys and distribution}

To determine the abundance of the Short-crested Coquette in the different habitats, 52 point counts were conducted along the altitudinal gradient. Twenty point counts each in the vicinity of El Molote and Nueva Delhi's towns, and 12 points near Paraiso, all were separated by at least $250 \mathrm{~m}$. The point counts were distributed to represent the heterogeneity of each study site (Fig. 1). Each point count had a fixed radius of $20 \mathrm{~m}$ and was monitored for $10 \mathrm{~min}$, during which all hummingbirds were recorded. Between the arrival at the point and the start of sampling, one minute of standing time was left to lessen the effect of the observer's presence. Following Bustamante-Castillo et al. (2020), in each plot we recorded the hummingbird species that visited flowers and plant species that were visited.

Fig. 1. Map of observations of Lophornis brachylophus recorded in eBird and study sites.

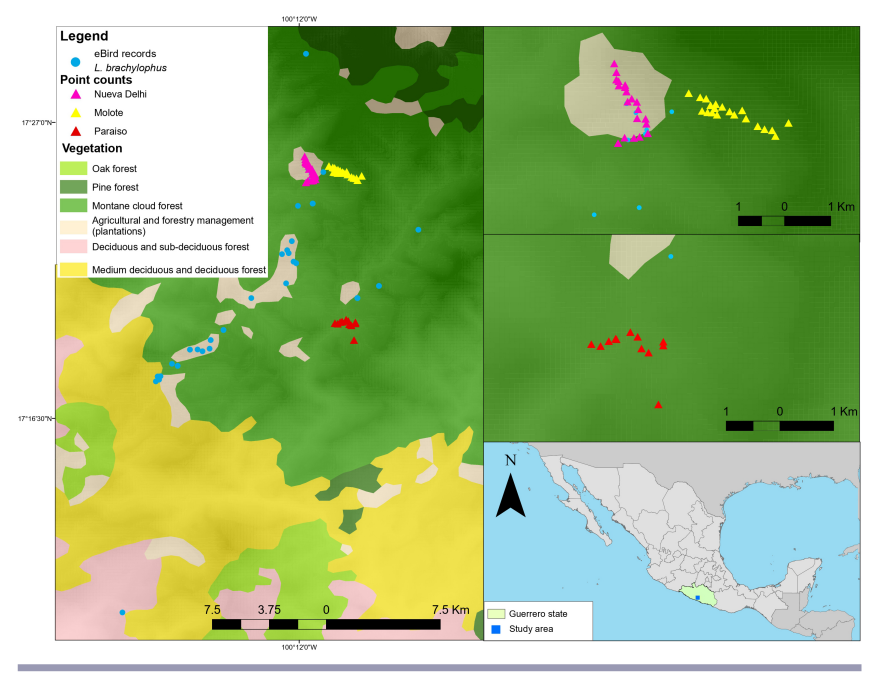

To better document the distribution of Short-crested Coquette, all existing records from the literature and observational databases were compiled (aVerAves/ebird; CONABIO 2016).

\section{Flower resources}

The availability of the flowers used by the Short-crested Coquette was recorded in phenological plots distributed in the three sites. The observations were carried out between 7:00 and 11:00 hours for four consecutive days in 2011 (in March, and in each month 
Table 1. Species-level network indices (degree, species strength, specialization d', betweenness and closeness centrality) and core-periphery. Core species name bold.

\begin{tabular}{|c|c|c|c|c|c|c|}
\hline & $\begin{array}{c}\text { Core- } \\
\text { periphery }\end{array}$ & Degree & $\begin{array}{c}\text { Species } \\
\text { strength }\end{array}$ & Specialization d', & Betweenness & Closeness \\
\hline Archilochus alexandri & -0.714 & 1 & 0.25 & 0.604 & 0 & 0.052 \\
\hline Archilochus colubris & -0.317 & 3 & 0.179 & 0.133 & 0 & 0.070 \\
\hline Campylopterus hemileucurus & -0.317 & 3 & 0.250 & 0.184 & 0.0175 & 0.073 \\
\hline Cynanthus auriceps & -0.516 & 2 & 0.75 & 0.695 & 0 & 0.057 \\
\hline Eupherusa poliocerca & 3.254 & 21 & 13.242 & 0.378 & 0.151 & 0.080 \\
\hline Heliomaster longirostris & 0.278 & 6 & 1.605 & 0.435 & 0.018 & 0.073 \\
\hline Heliomaster constantii & -0.516 & 2 & 0.127 & 0.181 & 0.018 & 0.073 \\
\hline Lophornis brachylophus & 0.675 & 8 & 3.807 & 0.763 & 0.601 & 0.083 \\
\hline Phaethornis mexicanus & -0.119 & 4 & 1.616 & 0.509 & 0 & 0.061 \\
\hline Saucerottia beryllina & 0.278 & 6 & 1.298 & 0.352 & 0.151 & 0.080 \\
\hline Selasphorus platycercus & 0.079 & 5 & 1.929 & 0.516 & 0 & 0.070 \\
\hline Selasphorus heloisa & -0.714 & 1 & 0.25 & 0.604 & 0 & 0.052 \\
\hline Selasphorus rufus & -0.714 & 1 & 0.333 & 0.686 & 0 & 0.048 \\
\hline Selasphorus calliope & -0.714 & 1 & 0.25 & 0.604 & 0 & 0.052 \\
\hline Tilmatura dupontii & 0.079 & 5 & 1.115 & 0.353 & 0.045 & 0.076 \\
\hline
\end{tabular}

from June to October). The plant species visited by each hummingbird species were also recorded. In each plot, the number of flowers of plant species with ornithophilic syndrome (tubular corolla, bright colors, and presence of nectar as a reward) and other flowers reported as used by hummingbirds were registered. The plant species were identified in the laboratory using herbarium specimens, guidebooks, and photographic records and by consulting with specialists.

\section{Short-crested Coquette behavior}

To establish which floral resources were used by the Short-crested Coquette and to understand how individuals of this species interact with those of other hummingbird species, behavioral observations were made for one day at each study site. All observed hummingbird species and plants visited by them were registered; when possible, hummingbird sex and age were noted. Each phenological plot was observed for 60 minutes, and all individual visits to flowers were registered. Also, all aggressive interactions involving Short-crested Coquettes were recorded (Cotton 1998).

\section{Network analysis}

We built quantitative networks of the interactions between plant and hummingbird species, with focal observations and point counts observations. We counted one visit (with or without making contact with reproductive structures of flowers) when a hummingbird fed on at least one flower and considered the number of visits as a measure of interaction strength (Maruyama et al., 2019). We recorded $r_{i j}=1$ if plant $i$ was visited by hummingbird $j$ and $\mathrm{r}_{i j}=0$ if no interaction occurred. We used the $\mathrm{R}$ Bipartite package to build the quantitative networks (Dormann et al. 2008, R Development Core Team 2019) and calculated the following metrics: nestedness (NODF), specialization $\left(\mathrm{H}_{2}{ }^{\prime}\right)$, connectance $(\mathrm{C})$, and modularity $(Q)$. Nestedness is a topological pattern that measures the separation of species' systematic arrangement by niche width (Dormann et al. 2009, Guimarães and Guimarães 2006). If the NODF value is close to 0 , there is no evidence of aggregation in the matrix; as it approached 100, the interactions can be considered increasingly nested (Dormann et al. 2009). To calculate network-level specialization, we used the specialization index $\mathrm{H}_{2}$, which is defined as the diversity of species interactions within the network considering the minimum $\left(\mathrm{H}_{2} \mathrm{~min}\right)$ and maximum $\left(\mathrm{H}_{2} \max \right)$ number of possible interactions (Bluthgen et al. 2006, Dormann et al. 2009). We calculated the connectance $(\mathrm{C})$ as the fraction of interactions recorded to the total possible at the community level (Dormann et al. 2009); more interconnected communities tend to be more stable (Dunne et al. 2002). Connectance values range from 0 to 1 ; if each animal visited each plant species, the connectance would be equal to 1 (Dormann et al. 2009). To calculate the modularity (Q), we used the QuanBiMo algorithm that computes modules in weighted, bipartite networks, based on a hierarchical representation of species link weights and optimal allocation to modules (Dormann and Strauss, 2014). We started with the number of Markov chain Monte Carlo (MCMC) moves to the point with no improvement in yield before the algorithm stops set to 107 steps (Dormann and Strauss 2014). The modularity $(Q)$ measures aggregated sets of interacting species within the network, ranging from 0 to 1 (Dormann and Strauss 2014). The higher the $Q$ value indicates that the data support the division of a network into modules. Following Maruyama et al. (2014), we performed 50 independent runs and retained the module conformation with the highest $Q$ value because the algorithm is stochastic, the module arrangement can vary between each run. We evaluated whether the $\mathrm{Q}$ value of each network is different from expected by chance, performing a null model ("null model 2") for $Q$ values with 100 network replicates generated randomly, considering the observed species richness and heterogeneity of the interaction. Also, we evaluated whether the network metrics (NODF, $\mathrm{H}_{2}{ }^{\prime}$, and $\mathrm{C}$ ) are different from expected by chance, performing a null model (r2dtable) for values with 1000 network replicates generated randomly, considering the matrix sum and row/column sums as constant (Bascompte et al. 2003).

To calculate species level (degree, species strength, betweenness, closeness, and specialization) of hummingbird species within the interaction networks, we used the function "specieslevel" in the bipartite package (Blüthgen et al. 2006, Dormann et al. 2008). We also calculated network core $(\mathrm{Gc})$ as: $\mathrm{Gc}=(\mathrm{ki} / \mathrm{kmean}) / \sigma \mathrm{k}$, 
where ki is the mean number of links for a given hummingbird or plant species, kmean is the mean number of links between all hummingbird or plant species in the network, and $\sigma \mathrm{k}$ is the standard deviation of the mean number of links between all hummingbird or plant species (Dáttilo et al. 2013). A Gc value greater than one indicates species with a higher number of interactions related to other species of the same trophic level; these can be considered the generalist nucleus (Dáttilo et al. 2013).

To simulate node extinctions and robustness calculations for different scenarios, we used the bipartite package (Dormann et al. 2008). We simulated three extinction scenarios of species: in the first scenario, species were randomly removed (plant and hummingbird species); in the second scenario, species were removed from the most to the least linked or more to the less degree within the network (plant and hummingbird species), and in the third scenario, hummingbird species were removed from most endangered to least endangered (only hummingbird species). First, we considered endangered species (NOM-059 SEMARNAT), second the endemic species, and last, the distribution range for the third extinction. Each simulated noderemoval scenario was running 100 times and robustness was calculated. The robustness is the proportion of species in a trophic level that remains in a bipartite network after sequential extirpation of species in the other trophic level and calculated as the area below the Attack Tolerance Curve (Vizentin-Bugoni et al. 2020).

\section{Statistical analysis}

For the statistical analysis, we used generalized linear models (GLMs) with a Poisson distribution. We considered the number of hummingbird species and number of Short-crested Coquette individuals as dependent variables and the number of plant species with flowers and number of flowers as independent variables. We made all figures in $\mathrm{R}$ Program ver. 3.6.1 ( $\mathrm{R}$ Development Core Team 2019), and we used the bipartite (Dorman et al. 2016) and vegan (Oksanen et al. 2014) packages for network analysis, the lme4 package (Bates et al. 2015) for the GLMs, and the ggplot2 package (Wickham 2016) for generating graphics.

\section{RESULTS}

\section{Distribution}

The Short-crested Coquette's distribution is highly restricted to pine-oak forest, pine, deciduous forest, and cloud forest in the Sierra de Atoyac in Guerrero. In the eBird database, we found 88 observations of the Short-crested Coquette (corresponding to 136 individuals observed). Most observations were recorded in cloud forest (86.48\%; see Fig. 1) and the remaining in coffee-growing areas $(13.52 \%)$.

\section{Hummingbird surveys}

The Short-crested Coquette was recorded throughout the year along the studied altitudinal gradient. From March to October, it was detected at the lower part of the gradient around Paraiso. During the beginning and end of winter, it moved to higher altitudes following the distribution of visited flowers (see Fig 2).
A total of 19 hummingbird species were detected in the study area (Fig. 3). The Short-crested Coquette represented $9 \%$ of all records (13 individuals observed). The most abundant species was the White-tailed Hummingbird (Eupherusa poliocerca), representing $52 \%$ of records. The following hummingbirds were also found in decreasing order of abundance: the Mexican Hermit (Phaethornis mexicanus), Berylline Hummingbird (Saucerottia beryllina), Long-billed Starthroat (Heliomaster longirostris), Violet Sabrewing (Campylopterus hemileucurus), and Bumblebee Hummingbird (Selasphorus heloisa; Fig. 3).

Fig. 2. Observed individuals of Lophornis brachylophus at each site during the sampling months. The number indicates the registers of Lophornis brachylophus in each site and month.

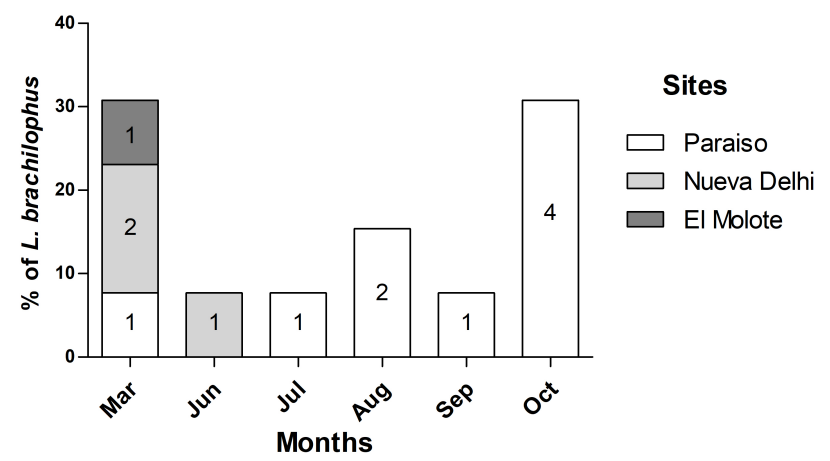

Fig. 3. Relative abundance of hummingbird species at Sierra de Atoyac.

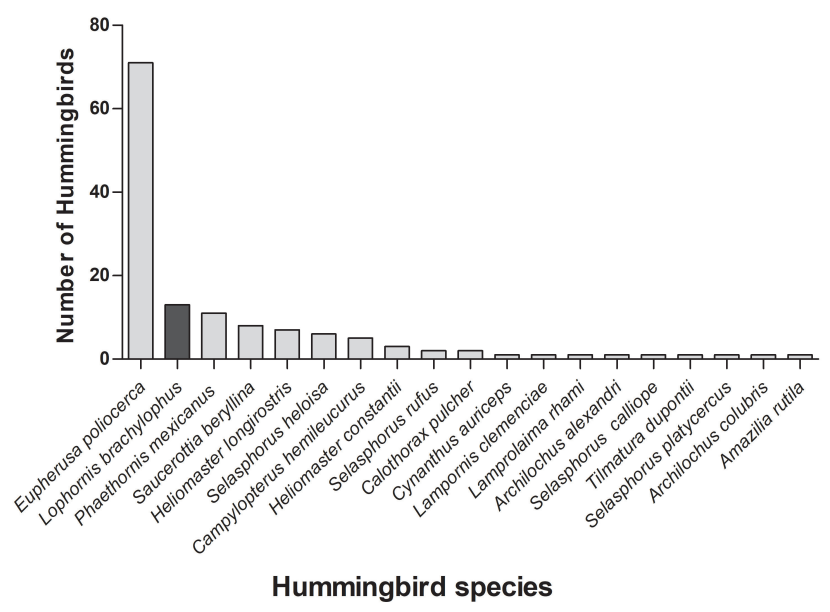

\section{Floral resources}

The Short-crested Coquette moved along the altitudinal gradient following the flowering of the plants on which it feeds. In March 2011, it was widely distributed along the gradient and was associated with the presence of flowers. During summer, flowering plants were restricted to the lower areas of the gradient, 
and hummingbirds were detected in those areas. The number of detected hummingbirds and number of flowers was positively and significantly related $(Z=2.758, P=0.005)$. At El Molote, at the top of the gradient, the Short-crested Coquette was only detected once when flowers were found. The number of plant species was significantly related to the number of flowers and Short-crested Coquette individuals $(\mathrm{Z}=3.401, p<0.001)$, yet the number of flowers was not related to the number of Short-crested Coquette individuals $(Z=1.610, p=0.107)$.

\section{Hummingbird-plant network}

The Hummingbird-plant data set comprised a total of 179 interactions between 27 plant species belonging to 17 families and 15 hummingbird species. The Short-crested Coquette fed on eight plant species out of the 27 species visited by hummingbirds in the study area (Fig. 4). Network specialization $\left(\mathrm{H}_{2}{ }^{\prime}=0.463\right)$ and modularity $(\mathrm{Q}=0.484)$ were significantly different from null models; network connectance $(0.170)$, and nestedness $(\mathrm{NODF}=$ 43.075) were not different from null models ( $Z$ test, $P$-values $>$ $0.05)$.

The endemic and endangered White-tailed Hummingbird visited 21 plant species, was a core species, and had the highest level of degree, species strength, betweenness, and closeness (Table 1). Short-crested Coquettes visited eight plant species and had the higher species strength, core-periphery, betweenness, and closeness (Table 1). Core plant species were Psittacanthus ramiflorus (visited by nine hummingbird species) and Musa sp. (visited by six hummingbird species) (Fig. 4). The Short-crested Coquette had a higher specialization level (Table 1).

In plant species' extinction scenarios, robustness of randomextinction scenarios $(\mathrm{R}=0.742)$ was higher than the most-toleast-linked scenarios $(\mathrm{R}=0.434)$. When robustness was compared at the three scenarios of hummingbird species loss, we found that random-extinction scenarios had higher robustness $(\mathrm{R}$ $=0.615)$ than most-to-least-linked scenarios (more to less degree) $(\mathrm{R}=0.293)$ and vulnerability status $(\mathrm{R}=0.348)$. It is important to highlight that the vulnerability-status scenario had a similar robustness to the most-to-least-linked scenario (Fig. A2.1).

\section{Feeding behavior}

The Short-crested Coquette is clearly a subordinated hummingbird. During focal observations we registered 46 females, 8 males, and 3 juveniles (only registered in Paraiso). Both males and females behaved similarly, following foraging routes and occasionally entering into the territories of dominant species. We observed a few interactions with other individuals, but the most agonistic interactions were with the White-tailed Hummingbird when visiting Clusia salvinii, where the ShortCrested Coquette lost all of the encounters (Fig. A2.2).

\section{DISCUSSION}

Our data indicated that the Short-crested Coquette is a species that moves along a small altitudinal gradient following the flowering of its preferred floral resources. It is subordinate and co-exists with at least 14 hummingbird species, some of which are territorial and dominant. Nonetheless, it is an important, rangerestricted, and specialist hummingbird species in the interaction network at the Bird Area Sierra de Atoyac.
Fig. 4. Hummingbird-plant visitation networks in the Atoyac, Guerrero. Hummingbird and plant species are indicated by boxes at the top and bottom, respectively. Box height represent the proportion of visits corresponding with each species in the network, and the thickness of each link indicates the frequency of each pairwise interaction. Blue boxes and lines indicate Lophornis brachylophus and their links. Red boxes indicate core species and black boxes indicate periphery species (Dáttilo et al. 2013).

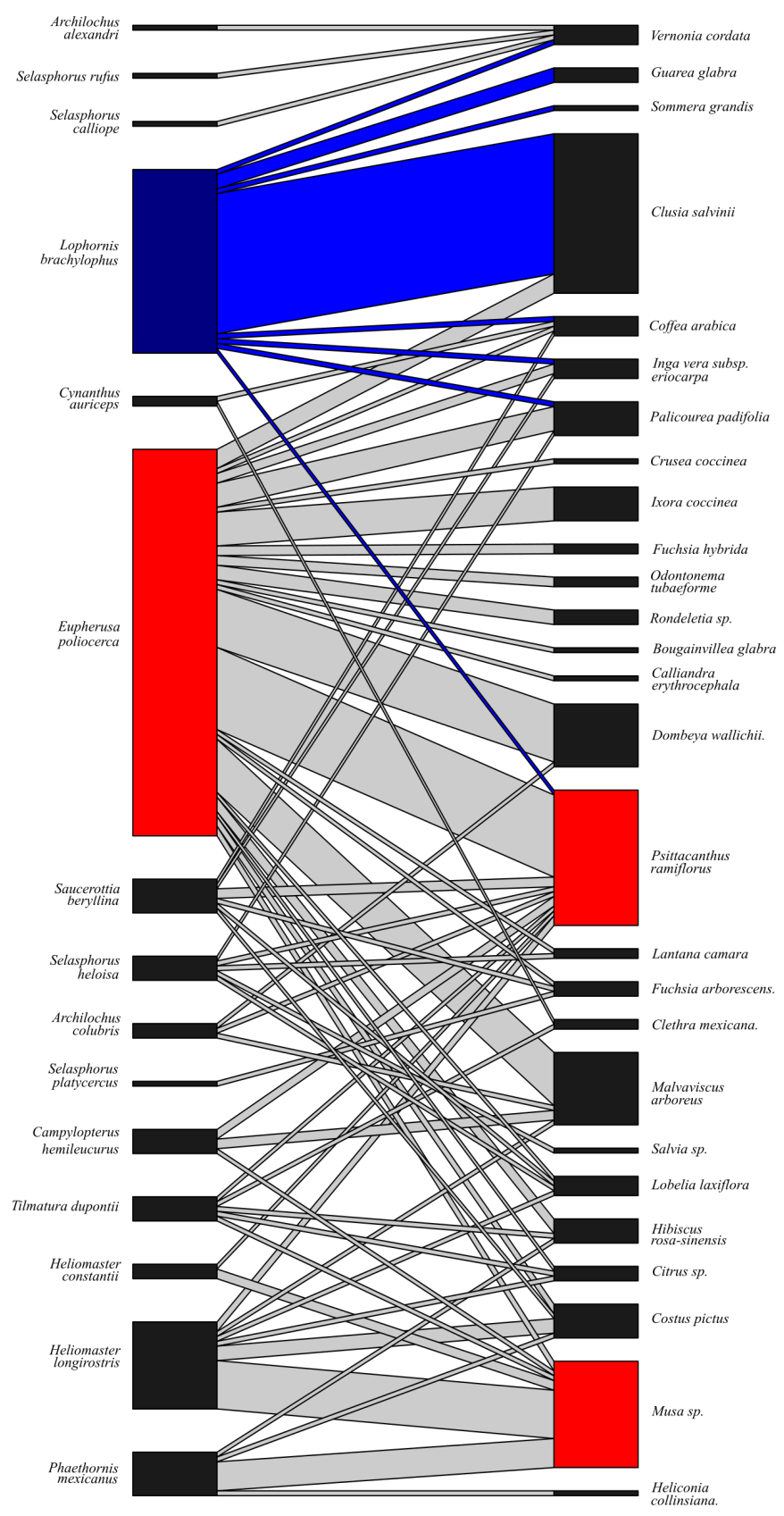




\section{Distribution}

The Short-crested Coquette is reportedly distributed between 900 and $1800 \mathrm{~m}$ asl (Schuchmann 1999). González-González and Hernández-Santana (2016) stated that the low mountain areas between 1100 to $1500 \mathrm{~m}$ asl are the best places for coffee cultivation at the Sierra de Atoyac. We found that the Short-crested Coquette was more abundant in the transition between cloud forest and semideciduous tropical forest around $1000 \mathrm{~m}$ asl (at Paraiso). Cloud forest is one of the most threatened ecosystems in Mexico and the world, mainly due to deforestation as a result of human activities and global warming (Toledo-Aceves et al. 2011, PonceReyes et al. 2012, Gual-Díaz and Rendón-Correa 2017). In the study region, the cloud forest below $1800 \mathrm{~m}$ asl is almost completely used for understory coffee cultivation; undisturbed forest only exists on steep slopes. Meanwhile, semideciduous tropical forest is rapidly being cleared for the cultivation of corn, fruits, and coffee (Navarro 1992).

Notably, coffee plantations are one of the main sources of income in the study region. More than $48 \%$ of the crops produced in Atoyac de Alvarez correspond to coffee plantations (Moguel and Toledo 1999). According to González-González and HernándezSantana (2015), 21753.2 ha are currently used for coffee production in Atoyac de Álvarez (13.95\% of the total area of the municipality). Given that the Short-crested Coquette feeds on the flowers of coffee plants, it is important to evaluate the energy supply of exotic plants such as coffee, in addition to the role of hummingbird species such as the Short-crested Coquette as pollinators of coffee plants; but it is also important to know the energy contribution of its main resource, Clusia salvinni. Therefore, Short-crested Coquette conservation is closely linked to the practices of coffee cultivation and the conservation of the few pristine areas of cloud forest in the region.

\section{Hummingbird surveys and floral resources}

Our findings confirmed that the conservation of the Short-crested Coquette depends on the preservation of the entire altitudinal gradient. Paraiso at the bottom of the gradient seems to be a very important site for the Short-crested Coquette, but it also appears that the upper parts are important during winter (as observed for other altitudinal hummingbirds in other areas of Mexico [Lyon 1976, Arizmendi 2001, López-Segoviano et al. 2017]). Rappole and Schuchmann (2003) estimated that 87 out of the 328 known hummingbird species (26.52\%) make altitudinal migrations, moving up or down foothills following the blooming of their preferred plant species (Des Ganges 1979, Arizmendi and Ornelas 1990, Hobson et al. 2003, Tinoco et al. 2009, Fraser et al. 2010). The main factor that influences the altitudinal migration of hummingbirds is the seasonal fluctuation of food resources (foodlimitation hypotheses; Levey and Stiles 1992, Des Ganges 1979, López-Segoviano et al. 2017, Hsiung et al. 2018); the cost and intensity of competition for those resources are also important factors (Wolf et al. 1976, Des Ganges 1979). However, other factors can explain altitudinal migrations, such as weather variation (i.e., changes in temperature, tropical storms) or predation risk. Skutch (1985) and Martin (2015) mentioned that if predation risk differs along an elevational gradient, animals can make altitudinal migrations to breed in sites with low predation risk (Hsiung et al. 2018) but information about the breeding of the Short-crested Coquette is not still available.

\section{Hummingbird-plant network}

The hummingbird-plant network specialization was low compared to the specialization reported by Maglianesi et al. (2014) but was similar to a previous meta-analysis study $\left(\mathrm{H}_{2}{ }^{\prime}=\right.$ 0.43; Schleuning et al. 2012). Sonne et al. (2016) found that hummingbird communities with high proportions of smaller ranged species also have a high ecological specialization degree. This study registered five endemic hummingbird species: Whitetailed Hummingbird, Short-crested Coquette, Golden-crowned Emerald, Mexican Hermit, and Bumblebee Hummingbird. The first two have restricted distributional ranges in Mexico. The hummingbird communities with higher proportions of smallerranged, specialized species may be vulnerable to disturbance and climate changes because communities composed of specialized species less prone to switching their interactions are at higher risk of secondary extinctions (Sonne et al. 2016)

In comparison to other studies from Mexico, the specialization we found was similar to Díaz-Infante et al. (2020) who worked in the tropical dry forest of Jalisco. Our measures of network components (connectance, nestedness, and modularity) which support network stability, were lower than in some other systems, for example, Díaz-Infante et al. (2020) and Maglianesi et al. (2014). However, they were similar to those reported by RamírezBurbano et al. (2017) who studied other endemic and endangered hummingbirds such as the Colorful Puffleg (Eriocnemis mirabilis) in Colombian Andes. Araujo et al. (2018) suggested that climate and spatial filters are determinants for the modularity in hummingbird-plant networks and also affect the cross-biome network structure. However, due to multiple factors, this network's temporary sampling effort is not complete; sampling effort can influence our understanding of interaction patterns but has a minor influence on identifying processes structuring a single ecological subnetwork (Vizentin-Bugoni et al. 2016).

Generalist core species are abundant and visit many plant species (Simmons et al. 2019). We found that the endangered and more abundant White-tailed Hummingbird was a generalist core species that visited 21 of 27 plant species, and the Short-crested Coquette has a high core-periphery $(G c=0.675)$ and visited eight plants species. As an example, the critically endangered Colorful Puffleg was observed visiting 15 of 27 plant species and 4 of 19 plant species of the hummingbird-plant networks from Munchique Natural National Park and its buffer zone in Colombia (Ramírez-Burbano et al. 2017). In the Munchique Natural National Park, the Colorful Puffleg was one of the most important hummingbird species (Ramírez-Burbano et al. 2017). Similarly, the critically endangered Short-crested Coquette was one of the most important hummingbird species within our visitation network.

Our results showed that the robustness of the vulnerability-status scenario (according to the species' risk status and their distribution) was lower than the random-extinctions scenario and higher than the most-to-least-linked scenario. When we removed the most-linked species of pollinators, the number of plant species decays faster than in random-extinction scenarios, the same was found by Memmott et al. (2014). The vulnerability-status scenario's robustness was similar to most-to-least-linked because endangered and endemic hummingbird species have many links. For example, the vulnerability-status scenario first eliminated 
critical endangered Short-crested Coquette which had eight links, and then eliminated endangered White-tailed Hummingbird which was a generalist core species and had 21 links. Solé and Montoya (2001) mentioned that extinctions of core species have huge consequences on network dynamics. Vizentin--Bugoni et al. (2020) stated that vertebrate pollinator-plant tropical networks are more susceptible to the loss of generalist than specialist species. According to Hadley et al. (2018) the absence of specialized hummingbird implies more generalized interaction networks. Our network has two generalist species as core species (White-tailed Hummingbird and Short-crested Coquette), this may have implications on the stability of the network because both species are listed with some degree of threat (SEMARNAT 2010). The extinction of the most connected species causes the network to collapse.

\section{Feeding behavior}

The Short-crested Coquette feeds on the flowers of eight plant species. Most flowers used by the Short-crested Coquette cannot be classified as ornithophilic flowers. Maruyama et al. (2013) found in a Brazilian Cerrado that non-ornithophilous floral resources are as important for hummingbirds as ornithophilous plants. Also, they established that flowers with bumblebee or bat/ hawkmoth syndrome are commonly visited by hummingbirds and contribute greatly to the total availability of energy in their habitats (Dalsgaard et al. 2009, Maruyama et al. 2013). It is important to understand the feeding ecology of the Short-crested Coquette in order to guide future restoration initiatives and propagation techniques (Guevara et al. 2017), especially considering that one of the main proposals for the conservation of at-risk hummingbirds is the conservation and restoration of their habitats (Anderson et al. 2010, Guevara et al. 2017).

However, it is possible that other hummingbirds with aggressive behavior are displacing the Short-crested Coquette, causing them to visit non-ornithophilic flowers (i.e., Clusia salvinii, Coffea arabica, and Sommera grandis). Small species such as the Shortcrested Coquette act as subordinates of larger species. In fact, less dominant hummingbird species may appear to prefer areas of poorer resource quality simply because they are forced out of more favorable habitat (Stiles 1976, Sandlin 2000, Muchhala et al. 2014, López-Segoviano et al. 2017). However, smaller-sized hummingbird species also require smaller quantities of nectar, rendering smaller species more efficient in the exploitation of less calorie-rich resources than larger hummingbirds (Wolf 1978). The nutritional quality of the floral resources used by hummingbirds in the study area has not yet been determined but would be important to investigate in the near future in order to better understand this phenomenon.

\section{Conservation}

The Short-crested Coquette is distributed across relics of cloud forest and coffee plantations. Coffee growers alter the habitat as they maintain trees as shade for coffee crops, manage the vegetation, and constantly cut the undergrowth. Also, pesticides are commonly used and represent a threat for hummingbirds and other pollinators that consume nectar from coffee flowers. Several authors have documented the presence of insecticide residues (neonicotinoid insecticides) on the nectar and pollen of crops and have mentioned that these could affect pollinators (Dively and Kamel 2012, Thompson et al. 2014, Bartlewicz et al. 2016,
Moreno-González et al. 2018). Additionally, Bishop et al. (2018) found pesticide compounds in cloacal fluids and fecal pellets of hummingbirds, although they did not comment on the potential effects of exposure. Therefore, it is necessary that future work evaluates the effect of coffee crop cultivation and management on the Short-crested Coquette, and hummingbirds in general, in the study region.

Morrison and Mendenhall (2020) found changes in diversity, composition, and interaction specialization in hummingbirdplant interactions in response to deforestation for coffee plantations and other agriculture; and according to Kattan et al. (1994) the fragmentation of an altitudinal gradient can lead to mass extinctions by disrupting altitudinal migrations. Likewise, the Short-crested Coquette is a core species, and its conservation is important because its presence in the community helps maintain the permanence of other hummingbirds and other plants (Kattan 1992). More studies and a conservation plan are needed to outline suitable economic activities and practices for the conservation of the most endangered, restricted, and endemic hummingbird species in Mexico.

Responses to this article can be read online at: https://www.ace-eco.org/issues/responses.php/1834

\section{Acknowledgments:}

The present work was supported by PAPIIT IN216617, IN221920 and IV200418 (MCA). Pronatura Chiapas collaborated in the initial part of the work with financial aid from BirdLife International and the American Bird Conservancy. L. E. NuñezRosas and G. López-Segoviano are grateful for the postdoctoral grant awarded by the Dirección General de Asuntos del Personal Académico (DGAPA) of the Universidad Nacional Autónoma de Mexico for their research carried out at the Facultad de Estudios Superiores Iztacala (L. E. Nuñez-Rosas) and Escuela Nacional de Estudios Superiores Campus Morelia (G. López-Segoviano).

\section{LITERATURE CITED}

Anderson, D. L., P. House, R. E. Hyman, R. Steiner, H. R. Hawkins, S. Thorn, M. J. Rey, M. R. Espinal, and L. E. Marineros. 2010. Rediscovery of the Honduran Emerald Amazilia luciae in western Honduras: insights on the distribution, ecology, and conservation of a 'Critically Endangered' hummingbird. Bird Conservation International 20:255-262. https://doi.org/10.1017/ S0959270910000389

Araujo, A. C., A. M. Martín González, B. Sandel, et al. 2018. Spatial distance and climate determine modularity in a crossbiomes plant-hummingbird interaction network in Brazil. Journal of Biogeography 45:1846-1858. https://doi.org/10.1111/jbi.13367

Argüello Cabrera, L. 2018. Violencia crónica y memoria pública. Entre rebeldes y víctimas, a propósito de Lucio Cabañas en Atoyac de Álvarez, Guerrero (2002-2018). Interdisciplina 8:87-112. https://doi.org/10.22201/ceiich.24485705e.2020.22.76420

Argüello Cabrera, L. 2019. Homicidios, cotidianidad y la 'Guerra contra el Narcotráfico'. Atoyac de Álvarez, Guerrero 
(2007-2014). Iztapalapa. Revista de ciencias sociales y humanidades 40:175-203. https://doi.org/10.28928/ri/872019/ aot2/arguellocabreral

Arizmendi, M. C., H. Berlanga, C. Rodríguez-Flores, V. VargasCanales, L. Montes-Leyva, and R. Lira. 2016. Hummingbird Conservation in Mexico: The Natural Protected Areas System. Natural Areas Journal 36:366-376. https://doi.org/10.3375/043.036.0404

Arizmendi, M. C. 2001. Multiple ecological interactions: nectar robbers and hummingbirds in a highland forest in Mexico. Canadian Journal of Zoology 76:997-1006. https://doi. org/10.1139/z01-066

Banks, R. C. 1990. Taxonomic status of the coquette hummingbird of Guerrero, Mexico. Auk 107:19 1-192.

Bartlewicz, J., M. I. Pozo, O. Honnay, B. Lievens, and H. Jacquemyn. 2016. Effects of agricultural fungicides on microorganisms associated with floral nectar: susceptibility assays and field experiments. Environmental Science and Pollution Research 23:19776-19786. https://doi.org/10.1007/s11356-016-7181-4

Bascompte, J., P. Jordano, C. Melian, and J. Olesen. 2003. The nested assembly of plant-animal mutualistic networks. Proceedings of the National Academy of Sciences of the United States of America 100:9383-9387. https://doi.org/10.1073/ pnas. 1633576100

Bates, D., M. Maechler, B. Bolker, and S. Walker. 2015. Fitting linear mixed-effects models using lme4. Journal od Statistical Software 67:1-48. http://doi.org/10.18637/jss.v067.i01

Beattie, A. J. 1971. A technique for the study of insect-borne pollen. Pan-Pacific Entomologist 47:82.

Berlanga, H., V. Rodríguez-Contreras, A. O. de Ita, M. Escobar, L. Rodríguez, J. Vieyra, and V. Vargas. 2008. Red de conocimientos sobre las aves de México ( AVESMX). Comisión Nacional para el Uso y Conocimiento de la Biodiversidad. http://avesmx. conabio.gob.mx/index.html

Bishop, C. A., A. J. Moran, M. C. Toshack, E. Elle, F. Maisonneuve, and J. E. Elliott. 2018. Hummingbirds and bumble bees exposed to neonicotinoid and organophosphate insecticides in the Fraser Valley, British Columbia, Canada. Environmental toxicology and chemistry 37:2143-2152. https://doi.org/10.1002/ etc. 4174

Buckland, S. T., D. R. Anderson, K. P. Burnham, and J. L. Laake. 1993. Distance sampling: estimating abundance of biological populations. Chapman and Hall, London, UK.

Blüthgen, N., F. Menzel, and N. Blüthgen. 2006. Measuring specialization in species interaction networks. BMC Ecology 6:9. https://doi.org/10.1186/1472-6785-6-9

CONABIO. 2016. aVerAves. Base de datos SNIB-CONABIO. Noviembre, 2020. México.

CONABIO. 2019. Bosques nublados. https://www.biodiversidad. gob.mx/ecosistemas/bosqueNublado.

Dalsgaard, B., A. González, J. M. Olesen, J. Ollerton, A. Timmermann, L. H. Andersen, and A. G. Tossas. 2009. Planthummingbird interactions in the West Indies: floral specialization gradients associated with environment and hummingbird size. Oecologia 159:757-766. https://doi.org/10.1007/s00442-008-1255$\mathrm{z}$

Dáttilo, W., P. R. Guimarães Jr., and T. J. Izzo. 2013. Spatial structure of ant-plant mutualistic networks. Oikos 122:1643-1648. doi: 10.1111/j.1600-0706.2013.00562.x.

Dively, G. P., and A. Kamel. 2012. Insecticide residues in pollen and nectar of a cucurbit crop and their potential exposure to pollinators. Journal of agricultural and food chemistry 60:4449-4456. https://doi.org/10.1021/jf205393x

Dormann, C. F., and R. Strauss. 2014. A method for detecting modules in quantitative bipartite networks. Methods in Ecology and Evolution 5:90-98. https://doi.org/10.1111/2041-210X.12139

Dormann, C., J. Fründ, N. Blüthgen, and B. Gruber. 2009. Indices, Graphs and Null Models: Analyzing Bipartite Ecological Networks. The Open Ecology Journal 2. https://doi. org/10.2174/1874213000902010007

Dormann, C., B. Gruber, and J. Fründ. 2008. Introducing the bipartite Package: Analysing Ecological Networks. $R$ News 8:8-11.

Dunne, J. A., R. J. Williams, and N. D. Martinez. 2002. FoodWeb Structure and Network Theory: The Role of Connectance and Size. Proceedings of the National Academy of Sciences of the United States of America 99:12917-12922. https://doi. org/10.1073/pnas.192407699

eBird. 2020. eBird Basic Dataset. Cornell Lab of Ornithology, Ithaca, New York

Estades, C. F., J. Aguirre, M. A. Escobar, J. A. Tomasevic, M. A. Vukasovic, and C. Tala. 2007. Conservation status of the Chilean Woodstar Eulidia yarrellii. Bird Conservation International 17:163-175. https://doi.org/10.1017/S0959270907000676

Freile, J.F., P. Piedrahita, G. Buitron-Jurado, C. A. Rodriguez, O. Jadan, and E. Bonaccorso. 2011. Observations on the natural history of the Royal Sunangel (Heliangelus regalis) in the Nangaritza Valley, Ecuador. Wilson Journal of Ornithology 123:85-92. https://doi.org/10.1676/10-054.1

Freymann, B. and Schuchmann, K. L. 2005. Collecting history of the hummingbird genera Chaetocercus Gray, 1855 and Lophornis Lesson, 1829. Journal of Ornithology 146: 61-64. https://doi.org/10.1007/s10336-004-0056-3

González-González, H. A., and J. R. Hernández-Santana. 2016. Zonificación agroecológica del Coffea arabica en el municipio Atoyac de Álvarez, Guerrero, México. Investigaciones Geográficas, Boletín del Instituto de Geografía 90:105-118. https:// doi.org/10.14350/rig.49329

Gotelli, N. J., and G. R. Graves. 1996. Null models in Ecology. Smithsonian Institution Press, Washington D.C., USA.

Gual-Díaz, M,. and A. Rendón-Correa. 2017. Los bosques mesófilos de montaña de México. Agroproductividad 10:3-9.

Guevara, E. A., R. Hipo, C. Poveda, B. Rojas, C. H. Graham, and G. T. Santander. 2017. Plant and habitat use by Blackbreasted Pufflegs (Eriocnemis nigrivestis), a critically endangered hummingbird. Journal of Field Ornithology 88:229-235. https:// doi.org/10.1111/jofo. 12208 
Guimarães, P. R., and P. Guimarães. 2006. Improving the analyses of nestedness for large sets of matrices. Environmental Modelling \& Software 21:1512-1513. https://doi.org/10.1016/j.envsoft.2006.04.002.

Hadley, A. S., S. J. K. Frey, W. D. Robinson, and M. G. Betts. 2018. Forest fragmentation and loss reduce richness, availability, and specialization in tropical hummingbird communities. Biotropica 50:74-83. https://doi.org/10.1111/btp.12487

Hernández-Baños, B. E., A. T. Peterson, A. G. Navarro-Sigüenza, and B. P. Escalante-Pliego. 1995. Bird faunas of the humid montane forests of Mesoamerica: biogeographic patterns and priorities for conservation. Bird Conservation International 5:251-277. https://doi.org/10.1017/S0959270900001039

Howell, S. N. G., and S. Webb. 1995. A guide to the birds of Mexico and Northern Central America. Oxford University Press, New York, USA.

Hsiung, A. C., A. W. Boyle, R. J. Cooper, and R. B. Chandler. 2018. Altitudinal migration: ecological drivers, knowledge gaps, and conservation implications. Biological Reviews 93:2049-2070. https://doi.org/10.1111/brv.12435

Hutto, R. L., S. M. Pletschet, and P. Hendricks. 1986. A fixedradius point count method for nonbreeding and breeding season use. Auk 103:593-602. https://doi.org/10.1093/auk/103.3.593

Johnsgard, P. A. 1997. The hummingbirds of North America. Smithsonian Institution Press, Washington D.C., USA.

Kattan, G. H. 1992. Rarity and vulnerability: the birds of the Cordillera Central of Colombia. Conservation Biology 6:64-70. https://doi.org/10.1046/j.1523-1739.1992.610064.x

Kattan, G. H., H. Alvarez-López, and M. Giraldo. 1994. Forest fragmentation and bird extinctions: San Antonio eighty years later. Conservation Biology 8:138-146. https://doi.org/10.1046/ j.1523-1739.1994.08010138.x

Kearns, C. A. and D. W. Inouye. 1993. Techniques for Pollination Biologist. University Press of Colorado, USA.

Lindberg, A. B. and J. M. Olesen. 2001. The fragility of extreme specialization: Passiflora mixta and its pollinating hummingbird Ensifera ensifera. Journal of Tropical Ecology 17: 323-329. https:// doi.org/10.1017/S0266467401001213

López-Segoviano, G., R. Bribiesca and M. C. Arizmendi. 2017. The role of size and dominance in the feeding behavior of coexisting hummingbirds. Ibis 160:283-292. https://doi. org/10.1111/ibi.12543

Lyon, D. L. 1976. A montane hummingbird territorial system in Oaxaca, Mexico. Wilson Bulletin 88:280-298. https://www.jstor. org/stable/4160743.

Martin, T. E. 2015. Age-related mortality explains life history strategies of tropical and temperate songbirds. Science 349: 966-970. https://doi.org/10.1126/science.aad1173

Maglianesi, M. A., Blüthgen, N., Böhning-Gaese, K., \& Schleuning, M. (2014). Morphological traits determine specialization and resource use in plant-hummingbird networks in the neotropics. Ecology, 95(12), 3325-3334. https://doi. org/10.1890/13-2261.1
Maruyama, P. K., C. Bonizário, A. P. Marcon, G. D’Angelo, M. M. da Silva, E. N. da Silva Neto, P. E. Oliveira, I. Sazima, M. Sazima, J. Vizentin-Bugoni, L. dos Anjos, A. M. Rui, and O. Marçal Júnior. 2019. Plant-hummingbird interaction networks in urban areas: Generalization and the importance of trees with specialized flowers as a nectar resource for pollinator conservation. Biological Conservation 230:187-194. https://doi. org/10.1016/j.biocon.2018.12.012

Maruyama, P.K., G. M. Oliveira, C. Ferreira, B. Dalsgaard and P. E. Oliveira. 2013. Pollination syndromes ignored: importance of non-ornithophilous flowers to Neotropical savanna hummingbirds. Naturwissenschaften 100:1061-1068. https://doi. org/10.1007/s00114-013-1111-9

Maruyama, P. K., J. Vizentin-Bugoni, G. M. Oliveira, P. E. Oliveira, and B. Dalsgaard. 2014. Morphological and SpatioTemporal Mismatches Shape a Neotropical Savanna PlantHummingbird Network. Biotropica 46:740-747. https://doi org/10.1111/btp.12170

Memmott, J., and N. M. Waser. 2002. Integration of alien plants into a native flower - pollinator visitation web. Proceedings of the Royal Society of London Series B: Biological Sciences 269:2395-2399. https://doi.org/10.1098/rspb.2002.2174

McGuire, J. A., C. C. Witt, J. V. Remsen Jr, R. Dudley, and D. L. Altshuler. 2009. A higher-level taxonomy for hummingbirds. Journal of Ornithology 150:155-165. https://doi.org/10.1007/ s10336-008-0330-x

McGuire, J. A., C. C. Witt, J. V. Remsen Jr, A. Corl, D. L. Rabosky, D. L. Altshuler, and R. Dudley. 2014. Molecular phylogenetics and the diversification of hummingbirds. Current Biology 24:910-916. https://doi.org/10.1016/j.cub.2014.03.016

Moreno-González, D., J. Alcántara-Durán, B. Gilbert-López, M. Beneito-Cambra, V. M. Cutillas, Ł. Rajski, A. Molina-Díaz, and J. F. García-Reyes. 2018. Sensitive detection of neonicotinoid insecticides and other selected pesticides in pollen and nectar using nanoflow liquid chromatography orbitrap tandem mass spectrometry. Journal of AOAC International 101:367-373. https://doi.org/10.5740/jaoacint.17-0412

Memmott, J., N. M. Waser, and M. V. Price. 2004. Tolerance of pollination networks to species extinctions. Proceedings of the Royal Society 271:2605-2611. https://doi.org/10.1098/rspb.2004.2909

Moguel, P., and V. M. Toledo. 1999. Biodiversity conservation in traditional coffee systems of Mexico. Conservation Biology 13:11-21. https://doi.org/10.1046/j.1523-1739.1999.97153.x

Morrison, B. M. and C. D. Mendenhall. 2020. HummingbirdPlant Interactions Are More Specialized in Forest Compared to Coffee Plantations. Diversity 12:126. https://doi.org/10.3390/ d12040126

Muchhala, N., S. Johnsen, and S. D. Smith. 2014. Competition for hummingbird pollination shapes flower color variation in Andean Solanaceae. Evolution 68:2275-2286. https://doi. org/10.1111/evo.12441

Navarro, S. A. 1998, Distribución geográfica y ecológica de la avifauna del Estado de Guerrero, México. PhD Thesis, Universidad Nacional Autónoma de México. 
Navarro S. A. G. 1992. Altitudinal distribution of birds in the Sierra Madre del Sur, Guerrero, Mexico. Condor 94:29-39. https:// doi.org/10.2307/1368793

Navarro-Sigüenza, A., H. Silva, M. Gual, L. Sánchez-González, and M. Pérez-Villafaña. 2014. La importancia de las aves del Bosque Mesófilo de Montaña de México. Pages 279-304

Ornelas, J. F. 1987. Rediscovery of the Rufous-crested Coquette (Lophornis delattrei brachylopha) in Guerrero, Mexico. Wilson Bulletin 99:719-721. https://www.jstor.org/stable/4162485

Ornelas, J. F., V. Sosa, D. E. Soltis, J. M. Daza, C. González, P. S. Soltis, C. Gutiérrez-Rodríguez, A. E. de los Monteros, T. A. Castoe, C. Bell, and E. Ruiz-Sanchez. 2013. Comparative Phylogeographic Analyses Illustrate the Complex Evolutionary History of Threatened Cloud Forests of Northern Mesoamerica. PLOS ONE 8:e56283. https://doi.org/10.1371/journal.pone.0056283

Ornelas, J. F. 1996. Origen y evolución de los colibríes. Ciencias 42:38-47.

Ponce-Reyes, R., V. H. Reynoso-Rosales, J. E. Watson, J. VanDerWal, R. A. Fuller, R. L. Pressey, and H. P. Possingham. 2012. Vulnerability of cloud forest reserves in Mexico to climate change. Nature Climate Change 2:448-452. https://doi. org/10.1038/nclimate1453

R Development Core Team. 2019. A language and environment for statistical computing. $\mathrm{R}$ Foundation for Statistical Computing, Vienna. [online] http://www.R-project.org/

Ramírez-Burbano, M. B., F. G. Stiles, C. González, F. W, Amorim, B. Dalsgaard, and P. K. Maruyama. 2017. The role of the endemic and critically endangered Colorful Puffleg Eriocnemis mirabilis in plant-hummingbird networks of the Colombian Andes. Biotropica 49:555-564. https://doi.org/10.1111/btp.12442

Sandlin, E.A. 2000. Cue use affects resource subdivision among three coexisting hummingbird species. Behavioral Ecology 11:550-559. https://doi.org/10.1093/beheco/11.5.550

Schuchmann, K. L. 1999. Family Trochilidae (Hummingbirds). Pp. 468-680 in J. del Hoyo, A. Elliot and J. Sargatal, editors. Handbook of the birds of the world. Volume 5: Barn-owls to hummingbirds. Lynx Editions, Barcelona, Spain. https://doi.org/ doi.org/10.2307/4089742

SEMARNAT. 2010. Norma Oficial Mexicana NOM-23759SEMARNAT-22371237, Protección ambiental-Especies nativas de México de flora y fauna silvestres-Categorías de riesgo y especificaciones para su inclusión, exclusión o cambio-Lista de especies en riesgo. Diario Oficial de la Federación, jueves 30 de diciembre de 2010. Gobierno de los Estados Unidos Mexicanos, Mexico D.F.http://www.profepa.gob.mx/innovaportal/file/435/1/ NOM_059_SEMARNAT_2010.pdf

Sierra-Morales, P., R. C. Almazán-Núñez, E. Beltrán-Sánchez, C. A. Ríos-Muñoz, and M. C. Arizmendi. 2016. Distribución geográfica y hábitat de la familia Trochilidae (Aves) en el estado de Guerrero, México. Revista de Biología Tropical 64:363-376. https://doi.org/10.15517/rbt.v64i1.18003

Simmons, B. I., J. Vizentin-bugoni, P. K. Maruyama, P. A. Cotton, O. H. Marín-gómez, C. Lara, L. Rosero-lasprilla, M. A.
Maglianesi, R. Ortiz-pulido, M. A. Rocca, L. C. Rodrigues, B. A. Tinoco, M. F. Vasconcelos, M. Sazima, A. M. M. González, J. Sonne, C. Rahbek, L. V Dicks, B. Dalsgaard, and W. J. Sutherland. 2019. Abundance drives broad patterns of generalisation in planthummingbird pollination networks. Oikos:1287-1295. https://doi. org/10.1111/oik.06104

Skutch, A. F. 1985. Clutch size, nesting success, and predation on nests of Neotropical birds, reviewed. Ornithological Monographs 36:575-594. https://doi.org/10.2307/40168306

Solé, R. V,. and J. M. Montoya. 2001. Complexity and fragility in ecological networks. Proceeding of Royal Society B 268:2039-2045. https://doi.org/10.1098/rspb.2001.1767

Sonne, J., A. M. Martín González, P. K. Maruyama, B. Sandel, S. Abrahamczyk, R. Alarcón, A. C. Araujo, F. P. Araujo, S. Mendes de Azevedo Jr, A. C. Baquero, D. Nogués-Bravo, P. A. Cotton, T. T. Ingversen, G. Kohler, C. Lara, F. M. Guedes LasCasas, A. O. Machado, C. G. Machado, M. A. Maglianesi, A. Cerqueira Moura, G. M. Oliveira, P. E. Oliveira, J. F. Ornelas, L. da Cruz Rodrigues, L. Rosero-Lasprilla, A. M. Rui, M. Sazima, M. Schleuning, A. Timmermann, I. Galarda Varassin, J. VizentinBugoni, Z. Wang, S. Watts, J. Fjeldså, J-C. Svenning, C. Rahbek, and B. Dalsgaard. 2016. High proportion of smaller-ranged hummingbird species coincides with ecological specialization across the Americas. Proceedings of the Royal Society B 283:20152512. https://doi.org/10.1098/rspb.2015.2512

Stiles, F. G. 1981. Geographical aspects of bird-flower coevolution, with particular reference to Central America. Annals of the Missouri Botanical Garden 68:323-351. https://www.jstor. org/stable/2398801 https://doi.org/10.2307/2398801

Stiles, F.G., 1976. Taste preferences, color preferences, and flower choice in hummingbirds. Condor 78:10-26. https://www.jstor.org/ stable/1366912 https://doi.org/10.2307/1366912

Thompson, H. M., S. Wilkins, S. Harkin, S. Milner, and K. F. Walters. 2015. Neonicotinoids and bumblebees (Bombus terrestris): effects on nectar consumption in individual workers. Pest management science 71:946-950. https://doi.org/10.1002/ ps.3868

Toledo-Aceves, T., J. A. Meave, M. Gonzalez-Espinosa, and N. Ramirez-Marcial. 2011. Tropical montane cloud forests: current threats and opportunities for their conservation and sustainable management in Mexico. Journal of environmental management 92:974-981. https://doi.org/10.1016/j.jenvman.2010.11.007

Torres-Chavez, M. G. and A. G. Navarro. 2000. Los Colibríes de México, brillo de la biodiversidad. Biodiversitas 28:2-6.

Vizentin-Bugoni, J., V. J. Debastiani, V. A. G. Bastazini, P. K. Maruyama, and J. H. Sperry. 2020. Including rewiring in the estimation of the robustness of mutualistic networks. Methods in Ecology and Evolution 11:106-116. https://doi.org/10.1111/2041-210X.13306.

Vizentin-Bugoni, J., P. K. Maruyama, V. J. Debastiani, L. da S. Duarte, B. Dalsgaard, and M. Sazima. 2016. Influences of sampling effort on detected patterns and structuring processes of a Neotropical plant-hummingbird network. Journal of Animal Ecology 85:262-272. https://doi.org/10.1111/1365-2656.12459. 
Wickham, H. 2016. ggplot2: elegant graphics for data analysis. Springer, New York, USA.

Wolf, L., F. G. Stiles, and F. R. Hainswoth. 1976. Ecological organization of a tropical highland hummingbird community. Journal of Animal Ecology 32:349-379. https://www.jstor.org/ stable/3879 https://doi.org/10.2307/3879

Wolf, L.L. 1978. Aggressive social organization in nectarivorous birds. American zoologist 18:765-778. https://doi.org/10.1093/ $\mathrm{icb} / 18.4 .765$

Züchner, T., P. F. D. Boesman, and C. J. Sharpe (2020). Shortcrested Coquette (Lophornis brachylophus), version 1.0. In: Birds of the World (J. del Hoyo, A. Elliott, J. Sargatal, D. A. Christie, and E. de Juana, Editors). Cornell Lab of Ornithology, Ithaca, NY, USA. https://doi.org/10.2173/bow.shccoq.01

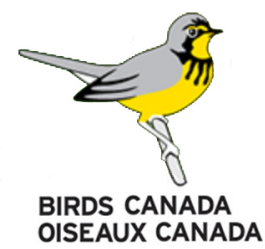


Appendix 1 Count points on Sierra de Atoyac, Guerrero.

Paraiso

$\begin{array}{rllll}\text { Point } & \text { Latitude N } & \text { Longitude } \mathrm{O} & \mathrm{m} \text { asl } & \text { Vegetation } \\ 1 & 17^{\circ} 19^{\prime} 53.1^{\prime \prime} & 100^{\circ} 10^{\prime} 43.9^{\prime \prime} & 1036 & \text { Tropical deciduos forest/ coffee plantations } \\ 2 & 17^{\circ} 19^{\prime} 51.9^{\prime \prime} & 100^{\circ} 10^{\prime} 38.2^{\prime \prime} & 1020 & \text { Tropical deciduos forest/ coffee plantations } \\ 3 & 17^{\circ} 19^{\prime} 54.9^{\prime \prime} & 100^{\circ} 10^{\prime} 33.3^{\prime \prime} & 1060 & \text { Tropical deciduos forest/ coffee plantations } \\ 4 & 17^{\circ} 19^{\prime} 56.0^{\prime \prime} & 100^{\circ} 10^{\prime} 28.7^{\prime \prime} & 1058 \text { Tropical deciduos forest/ coffee plantations } \\ 5 & 17^{\circ} 19^{\prime} 56.4^{\prime \prime} & 100^{\circ} 10^{\prime} 29.2^{\prime \prime} & 1060 \text { Tropical deciduos forest/ coffee plantations } \\ 6 & 17^{\circ} 20^{\prime} 00.3^{\prime \prime} & 100^{\circ} 10^{\prime} 20.3^{\prime \prime} & 1022 \text { Coffee plantations } \\ 7 & 17^{\circ} 19^{\prime} 57.5 & 100^{\circ} 10^{\prime} 15.9 & 1000 \text { Coffee plantations } \\ 8 & 17^{\circ} 19^{\prime} 50.4^{\prime \prime} & 100^{\circ} 10^{\prime} 13.6^{\prime \prime} & 1045 \text { Coffee plantations } \\ 9 & 17^{\circ} 19^{\prime} 47.9^{\prime \prime} & 100^{\circ} 10^{\prime} 09.4^{\prime \prime} & 1033 \text { Tropical deciduos forest/ coffee plantations } \\ 10 & 17^{\circ} 19^{\prime} 16.7^{\prime \prime} & 100^{\circ} 10^{\prime} 03.4^{\prime \prime} & 1056 \text { Tropical deciduos forest/ coffee plantations } \\ 11 & 17^{\circ} 19^{\prime} 52.3^{\prime \prime} & 100^{\circ} 10^{\prime} 03.0^{\prime \prime} & 1120 \text { Tropical deciduos forest/ coffee plantations } \\ 12 & 17^{\circ} 19^{\prime} 54.5^{\prime \prime} & 100^{\circ} 10^{\prime} 00.4 " & 1147 \text { Tropical deciduos forest/ coffee plantations }\end{array}$

\begin{tabular}{|c|c|c|c|c|}
\hline \multicolumn{5}{|c|}{ Nueva Delhi } \\
\hline Point & Latitude N & Longitude $\mathrm{O}$ & $\mathrm{m}$ asl & Vegetation \\
\hline 1 & $17^{\circ} 25^{\prime} 47.8^{\prime \prime}$ & $100^{\circ} 11^{\prime} 48.5^{\prime \prime}$ & 1525 & Cloud forest/ coffee plantations \\
\hline 2 & $17^{\circ} 25^{\prime} 41.8^{\prime \prime}$ & $100^{\circ} 11^{\prime} 47.11^{\prime \prime}$ & 1514 & Cloud forest/ coffee plantations \\
\hline 3 & $17^{\circ} 25^{\prime} 35.5^{\prime \prime}$ & $100^{\circ} 11^{\prime} 45.6^{\prime \prime}$ & 1501 & Cloud forest/ coffee plantations \\
\hline 4 & $17^{\circ} 25^{\prime} 32.8^{\prime \prime}$ & $100^{\circ} 11^{\prime} 40.9^{\prime \prime}$ & 1487 & Coffee plantations \\
\hline 5 & $17^{\circ} 25^{\prime} 31.3^{\prime \prime}$ & $100^{\circ} 11^{\prime} 41^{\prime \prime}$ & 1458 & Cloud forest/ coffee plantations \\
\hline 6 & $17^{\circ} 25^{\prime} 36.6^{\prime}$ & $100^{\circ} 11^{\prime} 47^{\prime \prime}$ & 1419 & Cloud forest/ coffee plantations \\
\hline 7 & $17^{\circ} 25^{\prime} 32.4^{\prime \prime}$ & $100^{\circ} 11^{\prime} 45.3^{\prime \prime}$ & 1419 & Cloud forest/ coffee plantations \\
\hline 8 & $17^{\circ} 25^{\prime} 28.2^{\prime \prime}$ & $100^{\circ} 11^{\prime} 40^{\prime \prime}$ & 1428 & Garden \\
\hline 9 & $17^{\circ} 25^{\prime} 21.2^{\prime \prime}$ & $100^{\circ} 11 ' 39.2^{\prime \prime}$ & 1439 & Cloud forest/ coffee plantations \\
\hline 10 & $17^{\circ} 25^{\prime} 23.3^{\prime \prime}$ & $100^{\circ} 11^{\prime} 36.3^{\prime \prime}$ & 1399 & Cloud forest/ coffee plantations \\
\hline 11 & $17^{\circ} 25^{\prime} 21.1^{\prime \prime}$ & $100^{\circ} 11^{\prime} 32.8^{\prime \prime}$ & 1419 & Cloud forest/ coffee plantations \\
\hline 12 & $17^{\circ} 25^{\prime} 15.8^{\prime \prime}$ & $100^{\circ} 11^{\prime} 31.8 "$ & 1372 & Cloud forest/ coffee plantations \\
\hline 13 & $17^{\circ} 25^{\prime} 09.6^{\prime \prime}$ & $100^{\circ} 11^{\prime} 32.5^{\prime \prime}$ & 1376 & Garden \\
\hline 14 & $17^{\circ} 25^{\prime} 09.2^{\prime \prime}$ & $100^{\circ} 11 ' 26.6^{\prime \prime}$ & 1388 & Cloud forest/ coffee plantations \\
\hline 15 & $17^{\circ} 25^{\prime} 05.7^{\prime \prime}$ & $100^{\circ} 11^{\prime} 26.1 "$ & 1389 & Cloud forest/ coffee plantations \\
\hline 16 & $17^{\circ} 24^{\prime} 59.1 "$ & $100^{\circ} 11^{\prime} 25.1 "$ & 1320 & Cloud forest/ coffee plantations \\
\hline 17 & $17^{\circ} 24^{\prime} 56.7^{\prime \prime}$ & $100^{\circ} 11 ' 30.8^{\prime \prime}$ & 1333 & Cloud forest/ coffee plantations \\
\hline 18 & $17^{\circ} 24^{\prime} 55.9$ & $100^{\circ} 11 ' 34.8^{\prime \prime}$ & 1329 & Cloud forest/ coffee plantations \\
\hline 19 & $17^{\circ} 24^{\prime} 56.1^{\prime \prime}$ & $100^{\circ} 11^{\prime} 41.4^{\prime \prime}$ & 1314 & Cloud forest/ coffee plantations \\
\hline 20 & $17^{\circ} 24^{\prime} 52.2^{\prime \prime}$ & $100^{\circ} 11^{\prime} 45.9^{\prime \prime}$ & 1300 & Cloud forest/ coffee plantations \\
\hline
\end{tabular}

El Molote

Point Latitude $\mathrm{N}$ Longitude $\mathrm{O} \mathrm{m}$ asl Vegetation

$11^{\circ} 24^{\prime} 57.3^{\prime \prime} \quad 100^{\circ} 09^{\prime} 56.1^{\prime \prime} \quad 1709$ Cloud forest

$21^{\circ} 25^{\prime} 01.3^{\prime \prime} 100^{\circ} 09^{\prime} 58.4^{\prime \prime} \quad 1730$ Cloud forest

$317^{\circ} 25^{\prime} 02.2^{\prime \prime} 100^{\circ} 10^{\prime} 03.8^{\prime \prime} \quad 1735$ Cloud forest 


$\begin{array}{rrrrl}4 & 17^{\circ} 25^{\prime} 04.1^{\prime \prime} & 100^{\circ} 10^{\prime} 08.5^{\prime \prime} & 1720 \text { Cloud forest } \\ 5 & 17^{\circ} 25^{\prime} 06.3^{\prime \prime} & 100^{\circ} 10^{\prime} 12.6^{\prime \prime} & 1714 \text { Coffee plantations } \\ 6 & 17^{\circ} 25^{\prime} 09.4^{\prime \prime} & 100^{\circ} 10^{\prime} 16.6^{\prime \prime} & 1752 \text { Garden } \\ 7 & 17^{\circ} 25^{\prime} 15.1^{\prime \prime} & 100^{\circ} 10^{\prime} 19.3^{\prime \prime} & 1787 \text { Coffee plantations } \\ 8 & 17^{\circ} 25^{\prime} 12.1^{\prime \prime} & 100^{\circ} 10^{\prime} 24.8^{\prime \prime} & 1775 \text { Coffee plantations } \\ 9 & 17^{\circ} 25^{\prime} 14.3^{\prime \prime} & 100^{\circ} 10^{\prime} 28.1^{\prime \prime} & 1780 \text { Coffee plantations } \\ 10 & 17^{\circ} 25^{\prime} 17.5^{\prime \prime} & 100^{\circ} 10^{\prime} 33.2^{\prime \prime} & 1745 \text { Coffee plantations } \\ 11 & 17^{\circ} 25^{\prime} 19.5^{\prime \prime} & 100^{\circ} 10^{\prime} 37.7^{\prime \prime} & 1732 \text { Oak forest } \\ 12 & 17^{\circ} 25^{\prime} 16.6^{\prime \prime} & 100^{\circ} 10^{\prime} 38.5^{\prime \prime} & 1708 \text { Coffee plantations } \\ 13 & 17^{\circ} 25^{\prime} 18.7^{\prime \prime} & 100^{\circ} 10^{\prime} 41.4 " & 1693 \text { plantations } \\ 14 & 17^{\circ} 25^{\prime} 13.6^{\prime \prime} & 100^{\circ} 10^{\prime} 40.3^{\prime \prime} & 1676 \text { Coffee plantations } \\ 15 & 17^{\circ} 25^{\prime} 13.8^{\prime \prime} & 100^{\circ} 10^{\prime} 43.5^{\prime \prime} & 1648 \text { Coffee plantations } \\ 16 & 17^{\circ} 25^{\prime} 14.8^{\prime \prime} & 100^{\circ} 10^{\prime} 47.3^{\prime \prime} & 1630 \text { Cloud forest } \\ 17 & 17^{\circ} 25^{\prime} 20.1 " & 100^{\circ} 10^{\prime} 36.9^{\prime \prime} & 1601 \text { Cloud forest } \\ 18 & 17^{\circ} 25^{\prime} 23.2^{\prime \prime} & 100^{\circ} 10^{\prime} 44.5^{\prime \prime} & 1632 \text { Cloud forest } \\ 19 & 17^{\circ} 25^{\prime} 24.3^{\prime \prime} & 100^{\circ} 10^{\prime} 48.6 & 1655 \text { Cloud forest } \\ 20 & 17^{\circ} 25^{\prime} 27.1^{\prime \prime} & 100^{\circ} 10^{\prime} 56.6^{\prime \prime} & 1659 \text { Cloud forest }\end{array}$




\section{Appendix 2}

Figure A2.1. Extinction scenarios for the hummingbird-plant visitation networks in the Atoyac, Guerrero. Shows random extinctions, most to least linked (degree) and vulnerability status. $\mathrm{R}$ indicate a network robustness
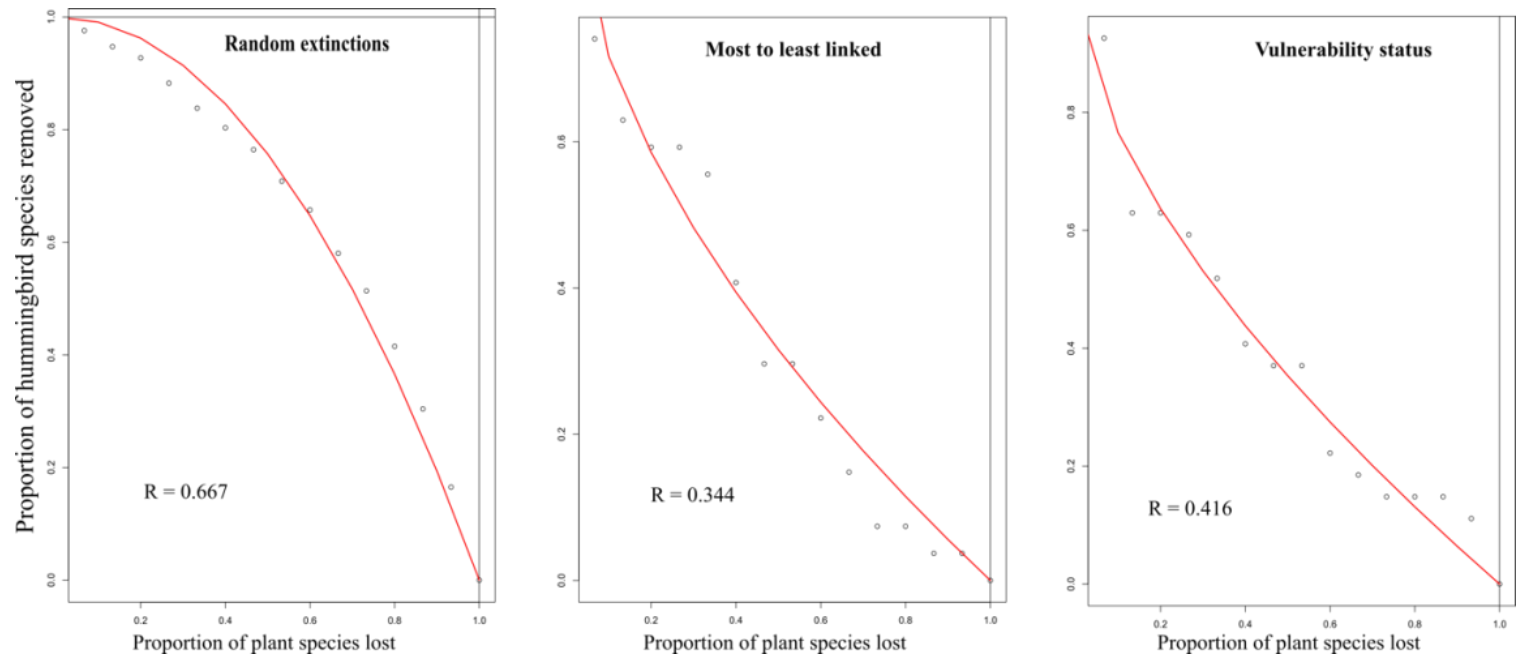

Figure A2.2. Intra- and interspecific interactions of Short-crested Coquette (Lophornis brachylophus).

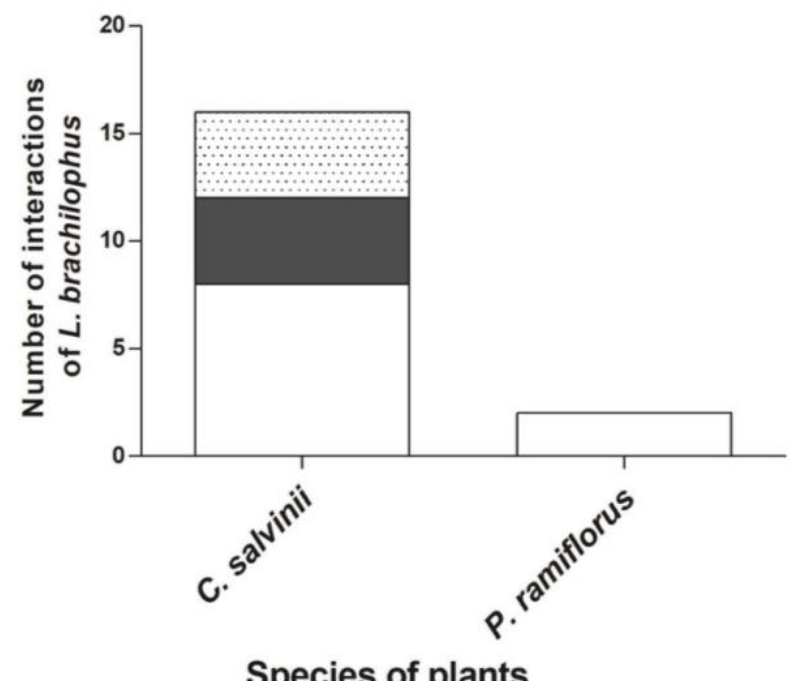

Lost with E. poliocerca

Lost with L. brachylophus

No aggression L. brachylophus

Species of plants 